\title{
Analyzing Factors That Influence the Behavior Intention of Consumer in Purchasing the Surabaya Apartment
}

\author{
Tika Dwi Septiani ${ }^{1}$ and Satria Fadil Persada ${ }^{2}$ \\ ${ }^{1}$ Department of Management Technology, Institut Teknologi Sepuluh Nopember, Surabaya \\ ${ }^{2}$ Department of Business Management, Institut Teknologi Sepuluh Nopember, Surabaya \\ e-mail: tikadwiseptiani@gmail.com
}

\begin{abstract}
The supplies of apartments in Surabaya keep increasing, which was predicted from 2018 to at least 2022. However, this supplies were contradicted with the demand from market, which is stagnant or decreased. The present research tries to measure the consumers' behavior intention towards the purchasing apartment. The well famous Theory of Planned Behavior (TPB) is used in this research as the measurement model. Furthermore, the TPB is extended with several factors. The extended TPB consists of seven factors namely: Attitude (ATT), Subjective Norms (SN), Perceived Behavior Control (PBC), Perception (P), Lifestyle (L), and the Behavior Intention (BI). Five hypotheses are proposed. The analysis on this research is confirmatory factor analysis (CFA) with structural equation model (SEM). The factors are instrumented through questionnaires. The questionnaires are distributed through offline and online sample with purposive sampling method. In more detail, the sampling will be taken from marketing events, brokers, and building management and the 300 respondents are targeted. The expected result from this research can be used as references for developers, consumers, and brokers in order to enhance the knowledge regarding the consumers' perception. From the results of the analysis of several factors from the Extended Theory of Planned Behavior mentioned above, it is known that the factors that are proven to influence consumer behavior intentions when making apartment purchases are 3 factors including the following: Attitude (ATT), Perception (P) and Lifestyle (L) while two other factors Subjective Norms (SN) and Perceived Behavior Control (PBC) are proven not to influence consumer behavior intentions when making apartment purchases.
\end{abstract}

Keywords-Apartment, Behavior Intention, Consumers Theory of Planned Behavior (TPB), Structural Equation Modelling (SEM).

\section{INTRODUCTION}

$\mathrm{I}_{\mathrm{s}}^{\mathrm{N}}$ $\mathrm{N}$ Indonesia the lifestyle of living in an apartment began in Jakarta and then the lifestyle spread to other cities such as Surabaya, Bandung and Jogjakarta. In Surabaya, apartment / condominium towers have begun to stand in many areas, not only as a single building, apartments \& condominiums also complete the construction of the superblock. Apartments in Surabaya are divided into 4 segments based on the selling price, including the mid-up segment with a selling price above 1.5 billion, mid-low segment with a selling price between 1 billion - 1.5 billion, a low segment with a selling price between 500 million - 1 billion, upper segment with selling price below 500M [1].

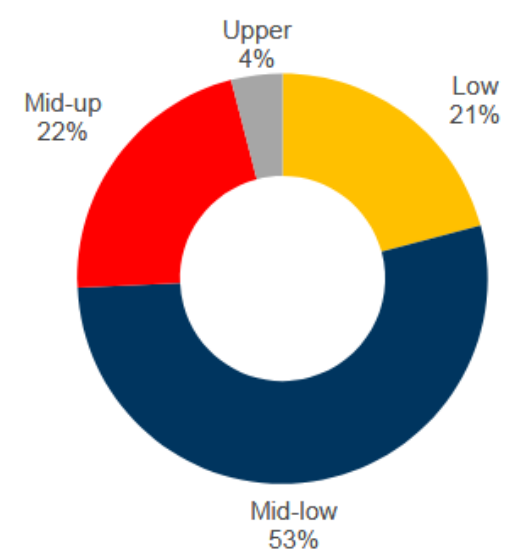

Figure 1. Market Segmentation of Existing Projects [1]

Based on market segmentation in the Figure 1, the lowest is the upper apartment segment by $4 \%$, the low by $21 \%$, the mid-up by $22 \%$, and the highest is the mid-low segment and dominates the apartment market in Surabaya at 53\%. Whereas the prediction of the apartment market in Surabaya up to $2020-2021$ in sequence from the lowest is the upper segment by $4 \%$, low segment by $7 \%$, mid-up segment by $41 \%$, and the highest is the mid-low segment. and dominates the apartment market in Surabaya at $48 \%$. Over the next 4 years since 2018 the availability of apartments in Surabaya will increase by 31,471 units from 44 projects. This shows an increase of $90 \%$ from 2018 which is 34,998 units if all projects can be completed on time

Market demand for apartments has increased insignificantly for existing projects, namely $0.1 \%$ from kurtal-1 to kurtal-2 in 2018. While for projects in the construction phase decreased market demand by $1.1 \%$ from $\mathrm{H} 1$ to $\mathrm{H} 2$ of 2018 , which is illustrated in Tabel 1. While market demand based on the area of distribution of apartment projects is illustrated in Tabel 2 [1].

This weakening market demand is caused by several factors including the general election, rising interest rates, the weakening of the rupiah against the dollar. However, demand still remains for new apartment projects with attractive designs, strategic locations, built by leading developers and offering attractive packages and promos such as full furnishings, free electronic equipment, attractive installment schemes, and also special discounts. 


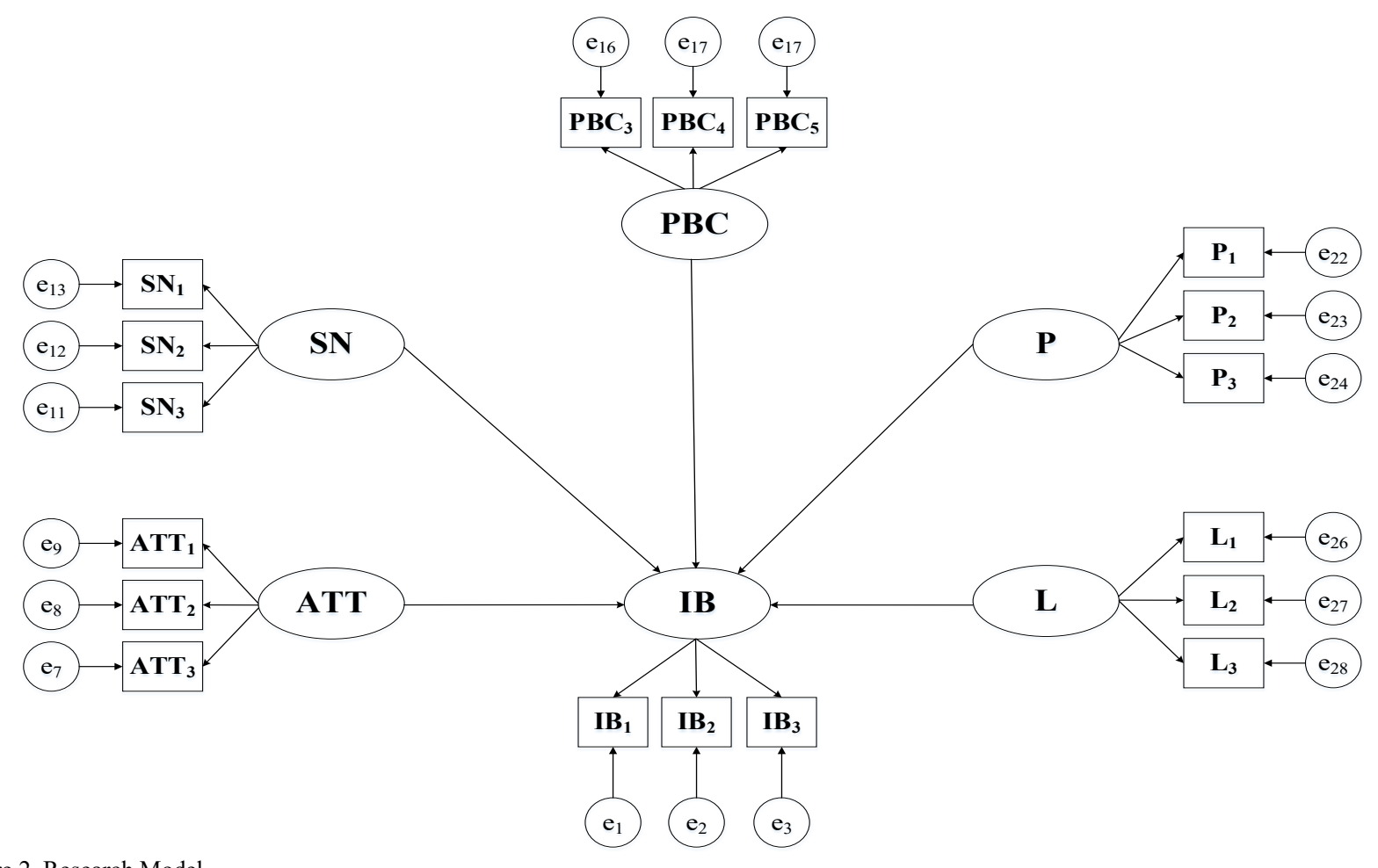

Figure 2. Research Model

Table 1.

Take-up Rate of Existing \& Under-Construction Apartments Formatting Rules

\begin{tabular}{lccccc}
\hline \hline & H2 2017 & H1 2018 & H2 2018 & HOH & YOY \\
\hline West Surabaya & $87.80 \%$ & $86.80 \%$ & $84.50 \%$ & $-2.30 \%$ & $-3.20 \%$ \\
East Surabaya & $80.30 \%$ & $85.50 \%$ & $85.00 \%$ & $-0.50 \%$ & $4.70 \%$ \\
South Surabaya & $83.00 \%$ & $72.20 \%$ & $70.40 \%$ & $-1.80 \%$ & $-12.70 \%$ \\
Central Surabaya & $67.60 \%$ & $72.60 \%$ & $75.80 \%$ & $3.20 \%$ & $8.20 \%$ \\
\hline \hline
\end{tabular}

Several factors that influence the consumer's decision to purchase an apartment are divided into two, namely internal \& external factors. Consumer internal factors include purchasing power / income level, lifestyle, social level, etc. While external factors that influence include price, location, family environment, physical attributes of apartments, advertisements, and promotions.

To understand the relationship between consumer behavioral intentions in apartment purchases can use the theory put forward by Ajzen in 1985, namely Theory of Planned Behavior (TPB) about intention behavior, influenced by several factors, including: attitudes toward behavior (attitude), pressure social behavior (subjective norms), and control over behavior (perceived control behavior). This TPB is a theory of expansion of the Theory of Reasoned Action (TRA) put forward by Fishbein \& Icek Azen in 1975 about beliefs that influence attitudes then lead to intentions and then perform a behavior.

The purpose of this study is to fill the gap from previous research, where previous research discusses consumer purchase intentions based on TPB \& TRA theory by taking the variable perceived behavior control (PBC), subjective norms (SN), attitude (ATT) alone apart from other factors such as variable perception (P) and lifestyle (L) that affect consumers' intention to buy an apartment. So this research
Table 2.

Take-up Rate by Region

\begin{tabular}{lccccc}
\hline \hline & H2 2017 & H1 2018 & H2 2018 & HOH & YOY \\
\hline West Surabaya & $87.80 \%$ & $86.80 \%$ & $84.50 \%$ & $-2.30 \%$ & $-3.20 \%$ \\
East Surabaya & $80.30 \%$ & $85.50 \%$ & $85.00 \%$ & $-0.50 \%$ & $4.70 \%$ \\
South Surabaya & $83.00 \%$ & $72.20 \%$ & $70.40 \%$ & $-1.80 \%$ & $-12.70 \%$ \\
Central Surabaya & $67.60 \%$ & $72.60 \%$ & $75.80 \%$ & $3.20 \%$ & $8.20 \%$ \\
\hline \hline
\end{tabular}

will discuss the gap of previous research by adding some of the variables mentioned above.

This study aims to analyze the variables that influence consumer behavior intentions in purchasing apartments in Surabaya by using Theory of Planned Behavior (TPB). Where has another goal, which is to be able to provide input for practitioners \& academics in developing marketing management strategies that are good \& appropriate in current market conditions by knowing the variables that influence the intention to behave consumers in apartment purchases.

\section{METHOD}

The concept of the research carried out is to confirm the basic theories that have been reviewed in the literature review on the influence of attitude, subjective norms, perceived behavioral control, perception, lifestyle, on the intention to behave consumers in apartment purchases. The core concepts as the basis of this research include:

1. Attitude significantly influences consumer behavior intentions [2].

2. Subjective Norms significantly influences consumer behavior intentions [2].

3. Perceived Behavior Control significantly influences consumer behavior intentions [2]. 
The $1^{\text {st }}$ International Conference on Business and Engineering Management (IConBEM)

February $1^{\text {st }} 2020$, Institut Teknologi Sepuluh Nopember, Surabaya, Indonesia

Table 3.

Research Variables \& Indicators

\begin{tabular}{|c|c|c|c|}
\hline Latent Variables & Definition & Indicators & Definition \\
\hline \multirow{3}{*}{$\begin{array}{l}\text { Intention Behavior to } \\
\text { Buy (IB) } / \eta_{1} \\
\text { (Endogen) }\end{array}$} & \multirow[t]{3}{*}{$\begin{array}{l}\text { Purchase intention refers to the possibility of } \\
\text { consumers' willingness to buy a product. }\end{array}$} & Continue $\left(\mathrm{IB}_{1}\right)$ & $\begin{array}{l}\text { Individuals will continue to purchase apartments } \\
\text { in the future [4] }\end{array}$ \\
\hline & & Intend $\left(\mathrm{IB}_{2}\right)$ & $\begin{array}{l}\text { Individuals intend to buy an apartment in the } \\
\text { future [4] }\end{array}$ \\
\hline & & Plan $\left(\mathrm{IB}_{3}\right)$ & Individuals planning to buy an apartment [4] \\
\hline \multirow{3}{*}{$\begin{array}{l}\text { Attitude (ATT) } / \tau_{1} \\
\text { (Eksogen) }\end{array}$} & \multirow{3}{*}{$\begin{array}{l}\text { Is a behavior that reflects a person's level of } \\
\text { evaluation of a particular action. According to Ajzen } \\
\text { (1975) in Mariano (1993) }\end{array}$} & Positive $\left(\mathrm{ATT}_{1}\right)$ & Buying an apartment is a useful decision [4] \\
\hline & & Good $\left(\mathrm{ATT}_{2}\right)$ & Buying an apartment is a great idea [4] \\
\hline & & Wise $\left(\mathrm{ATT}_{3}\right)$ & Buying an apartment is a wise decision [4] \\
\hline \multirow[t]{3}{*}{$\begin{array}{l}\text { Subjective Norms } \\
(\mathrm{SN}) / \tau_{2} \text { (Eksogen) }\end{array}$} & \multirow{3}{*}{$\begin{array}{l}\text { Describe an external pressure or influence on } \\
\text { someone in deciding whether or not to conduct a } \\
\text { behavior. Every other person or group in the } \\
\text { environment around individuals plays a major role in } \\
\text { the formation of subjective norms. The greatest } \\
\text { influence usually comes from parents, spouses, } \\
\text { friends, relatives, other family members, the } \\
\text { community, etc. }\end{array}$} & Suggest $\left(\mathrm{SN}_{1}\right)$ & $\begin{array}{l}\text { The social environment advises individuals to } \\
\text { buy an apartment [4] }\end{array}$ \\
\hline & & Want $\left(\mathrm{SN}_{2}\right)$ & $\begin{array}{l}\text { The social environment wants individuals to buy } \\
\text { apartments [4] }\end{array}$ \\
\hline & & Agree $\left(\mathrm{SN}_{3}\right)$ & $\begin{array}{l}\text { The social environment agrees with the } \\
\text { individual's decision to buy an apartment [4] }\end{array}$ \\
\hline \multirow{3}{*}{$\begin{array}{l}\text { Perceived Behavior } \\
\text { Control (PBC) } / \tau_{3} \\
\text { (Eksogen) }\end{array}$} & \multirow{3}{*}{$\begin{array}{l}\text { Behavioral control is a condition of how easy or not } \\
\text { to conduct a behavior and the level of individual } \\
\text { control over the purpose of a behavior }\end{array}$} & Money $\left(\mathrm{PBC}_{3}\right)$ & $\begin{array}{l}\text { Individuals have enough money to buy an } \\
\text { apartment. [4] }\end{array}$ \\
\hline & & $\begin{array}{l}\text { Skill and } \\
\text { Knowledge }\left(\mathrm{PBC}_{4}\right)\end{array}$ & $\begin{array}{l}\text { Individuals have sufficient skills and knowledge } \\
\text { about apartments to make their own decisions. If } \\
\text { the individual wants to buy an apartment [4] }\end{array}$ \\
\hline & & $\begin{array}{l}\text { Complete Control } \\
\left(\mathrm{PBC}_{5}\right)\end{array}$ & $\begin{array}{l}\text { Individuals have full control over the purchase } \\
\text { of an apartment [4] }\end{array}$ \\
\hline \multirow[t]{3}{*}{$\begin{array}{l}\text { Perception }(\mathrm{P}) / \tau_{5} \\
\text { (Eksogen) }\end{array}$} & \multirow[t]{3}{*}{$\begin{array}{l}\text { Perception is related to recognizing, choosing, } \\
\text { organizing and interpreting stimuli to understand the } \\
\text { world. }\end{array}$} & Like $\left(\mathrm{P}_{1}\right)$ & $\begin{array}{l}\text { Individuals like the attributes of an apartment } \\
\text { (design, facilities, location, environment, } \\
\text { quality) [3] }\end{array}$ \\
\hline & & Satisfaction $\left(\mathrm{P}_{2}\right)$ & $\begin{array}{l}\text { Individuals who have bought apartment products } \\
\text { are satisfied \& comfortable and will buy again } \\
\text { [3] }\end{array}$ \\
\hline & & $\begin{array}{l}\text { Interested in } \\
\text { advertising and } \\
\text { promotion }\left(\mathrm{P}_{3}\right)\end{array}$ & $\begin{array}{l}\text { Individuals are interested in advertising and } \\
\text { promoting apartments }\end{array}$ \\
\hline \multirow[t]{3}{*}{$\begin{array}{l}\text { Lifestyle }(\mathrm{L}) / \tau_{6} \\
\text { (Eksogen) }\end{array}$} & \multirow{3}{*}{$\begin{array}{l}\text { Lifestyle refers to the unique ways in which } \\
\text { consumers live, how they spend their time and } \\
\text { money, and what they consider important - their } \\
\text { activities, interests and opinions. Lifestyles evolve } \\
\text { over time, so that the corresponding consumption } \\
\text { patterns can also change (Kelly, 1955; and Reynolds } \\
\text { and Darden, 1974). }\end{array}$} & Need $\left(L_{1}\right)$ & $\begin{array}{l}\text { Individuals need an apartment that suits their } \\
\text { lifestyle [3] }\end{array}$ \\
\hline & & Like $\left(\mathrm{L}_{2}\right)$ & $\begin{array}{l}\text { Individuals like apartments with innovation in } \\
\text { accordance with the current lifestyle market } \\
\text { trends [3] }\end{array}$ \\
\hline & & Want $\left(\mathrm{L}_{3}\right)$ & $\begin{array}{l}\text { Individuals want a beautiful apartment away } \\
\text { from the crowd }\end{array}$ \\
\hline
\end{tabular}

4. Perception significantly influences consumer behavior intentions [3].

5. Lifestyle significantly influences consumer behavior intentions [3].

Based on the core concepts which are the results of previous studies that have been reviewed in a literature review then a conceptual model is formed as a model that will be used as a basis for research according to Figure 2 .

\section{A. Variables and Indicators of Research}

In this research model there are latent variables and manifest variables. Latent variables/constructs are variables that have an indirect effect on manifest variables. Latent variables are divided into two namely endogenous and exogenous. Endogenous latent variables/dependent variables are variables that are influenced or caused by independent variables, namely the intention of consumers to behave in buying apartments in Surabaya (IB). While the exogenous latent variables/independent variables namely predictor or stimulus variables are variables that affect or cause the occurrence of dependent variables consisting of: Lifestyle (L), Perception (P), Perceived Behavior Control (PBC), Subjective Norm (SN), and Attitude (ATT). Manifest variable/indicator that functions to measure latent variables. This study uses 18 indicator variables in the form of statement items in the questionnaire attached in Table 3.

\section{B. Results}

1) Assumptions and Requirements for SEM Data Processing with AMOS

1. Sample size $=300->$ has fulfilled to be processed using SEM with AMOS software.

2. Estimation Method Used Maximum Likelihood (ML) because the number of samples in this study is 300 .

3. Normality Test, normality test aims to test whether the data in this study have a normal distribution or close to normal. Statistically, the data can be said to be normally distributed if the value of the critical ratio (c.r) skewness 


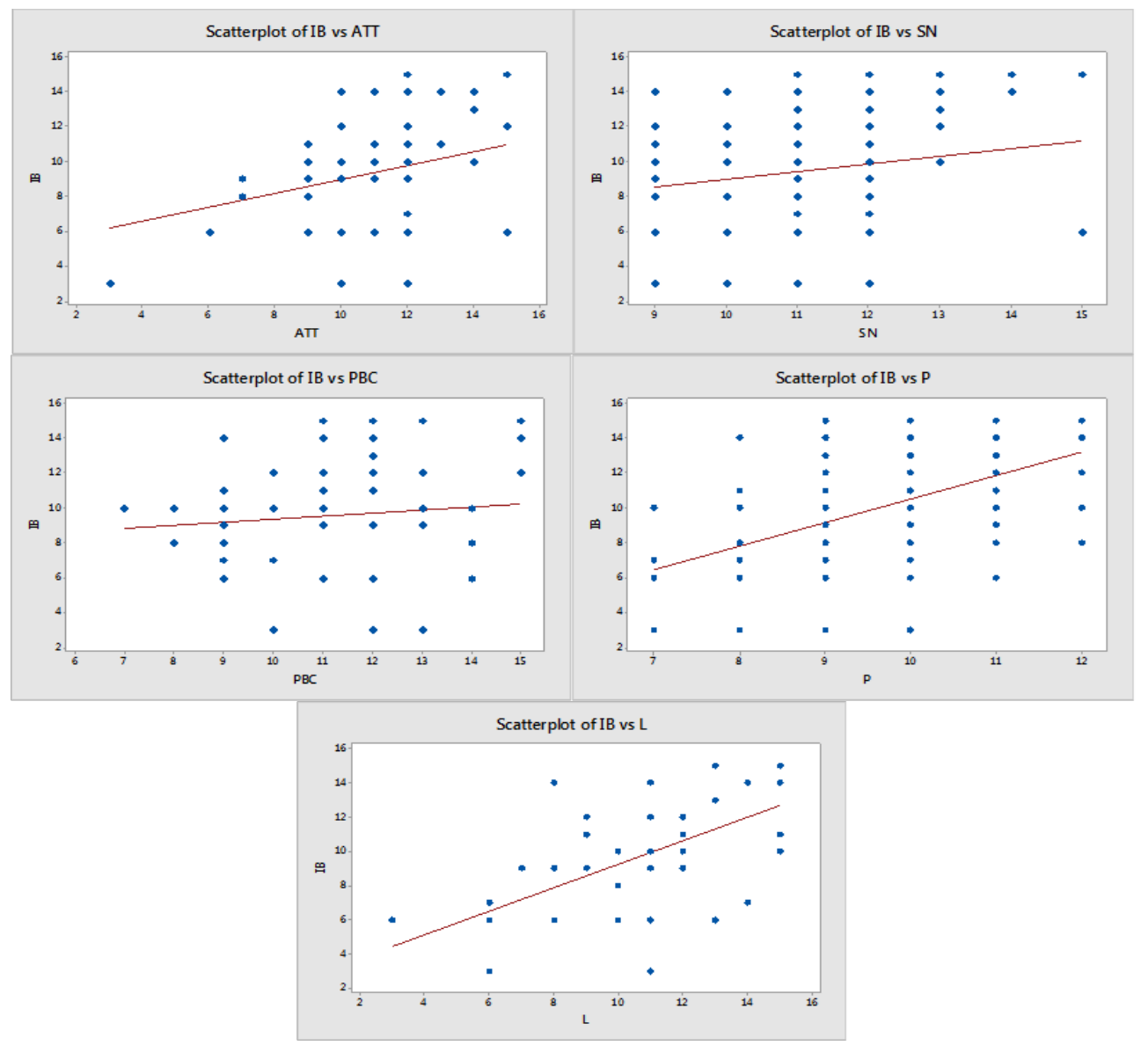

Figure 3. Results of Scatterplot Analysis of Relationships Between Latent Variables

Table 4.

Normality Test Result

\begin{tabular}{lcccccc}
\hline \hline Variable & min & max & skew & c.r. & kurtosis & c.r. \\
\hline P2 & 2 & 4 & 0.09 & 0.637 & -0.997 & -3.525 \\
PC5 & 2 & 5 & 0.201 & 1.423 & -0.962 & -3.4 \\
PC4 & 2 & 5 & 0.263 & 1.859 & -0.699 & -2.47 \\
PC3 & 1 & 5 & -0.237 & -1.673 & 0.452 & 1.598 \\
L3 & 1 & 5 & 0.101 & 0.717 & -1.447 & -5.115 \\
L2 & 1 & 5 & -0.203 & -1.437 & -1.334 & -4.717 \\
L1 & 1 & 5 & -0.419 & -2.961 & -1.119 & -3.957 \\
P3 & 2 & 3 & -0.539 & -3.808 & -1.71 & -6.046 \\
P1 & 3 & 5 & 0.222 & 1.572 & -0.617 & -2.182 \\
IB1 & 1 & 5 & -0.137 & -0.967 & -0.964 & -3.407 \\
IB2 & 1 & 5 & -0.179 & -1.263 & -1.2 & -4.243 \\
IB3 & 1 & 5 & 0.113 & 0.796 & -1.155 & -4.085 \\
ATT1 & 1 & 5 & -0.931 & -6.583 & 1.214 & 4.292 \\
ATT2 & 1 & 5 & -0.972 & -6.872 & 1.195 & 4.226 \\
ATT3 & 1 & 5 & -0.937 & -6.622 & 0.602 & 2.129 \\
SBN1 & 3 & 5 & 0.185 & 1.305 & -0.584 & -2.064 \\
SBN2 & 3 & 5 & 0.178 & 1.261 & -0.592 & -2.093 \\
SBN3 & 3 & 5 & 0.071 & 0.5 & -0.393 & -1.389 \\
Multivariate & & & & & 54.806 & 17.689 \\
\hline \hline
\end{tabular}

$\&$ kurtosis is +2.58 or between -2.58 and +2.58 . Table 4 shows the results of data normality testing. Based on Table 4 it is known that each indicator has a critical ratio value (cr) skewness and kurtosis partly between +2.58 and partly above +2.58 and a critical ratio (cr) value of multivariate above 2.58 is obtained, the assumption Univariate and multivariate normality has not yet been achieved.
Table 5 .

Outliers Findings

\begin{tabular}{cccc}
\hline \hline Observation number & Mahalanobis d-squared & p1 & p2 \\
\hline 17 & 62.658 & 0 & 0 \\
64 & 50.569 & 0 & 0 \\
58 & 46.681 & 0 & 0 \\
57 & 44.688 & 0 & 0 \\
59 & 39.91 & 0.002 & 0.001 \\
243 & 39.663 & 0.002 & 0 \\
83 & 37.862 & 0.004 & 0 \\
102 & 37.489 & 0.005 & 0 \\
142 & 37.489 & 0.005 & 0 \\
62 & 37.485 & 0.005 & 0 \\
182 & 37.349 & 0.005 & 0 \\
222 & 37.004 & 0.005 & 0 \\
262 & 37.004 & 0.005 & 0 \\
276 & 36.363 & 0.006 & 0 \\
2 & 35.965 & 0.007 & 0 \\
\hline \hline
\end{tabular}

4. Outliers, outlier findings are carried out as a treatment if the data are not normal. Following are the findings of outliers in the data attached in Table 5 . The number on the "Observation Number" shows the distance to a certain number point (Centroid) where the distance is measured by the mahalanobis method. The farther the distance of the data from the Centoid point, the possibility that the data is outlier.

5. The handling of this outlier data is to delete the data so that the data can be normally distributed, but in various studies where the empirical data used by respondents' 
The $1^{\text {st }}$ International Conference on Business and Engineering Management (IConBEM)

Table 6.

Linierirty F Results

\begin{tabular}{cccc}
\hline \hline Relationship between Variables & F (Deviation from Linierity) & Significancy (Sig.) & Information \\
\hline IB * ATT & 6.449 & 0 & Linear \\
IB * SN & 7.765 & 0 & Linear \\
IB * PBC & 10.113 & 0 & Linear \\
IB * P & 4.988 & 0.001 & Linear \\
IB * & 9.31 & 0 & Linear \\
\hline \hline
\end{tabular}

Table 7.

Multicollinearity Test Results

\section{Coefficients $^{a}$}

\begin{tabular}{|c|c|c|c|c|c|c|c|c|}
\hline \\
\hline \multirow{2}{*}{\multicolumn{2}{|c|}{ Model }} & \multicolumn{2}{|c|}{$\begin{array}{c}\text { Unstandardized } \\
\text { Coefficients }\end{array}$} & \multirow{2}{*}{$\begin{array}{c}\text { Standardized } \\
\text { Coefficients } \\
\text { Beta } \\
\end{array}$} & \multirow[b]{2}{*}{$t$} & \multirow[b]{2}{*}{ Sig. } & \multicolumn{2}{|c|}{$\begin{array}{l}\text { Collinearity } \\
\text { Statistics }\end{array}$} \\
\hline & & $\mathrm{B}$ & Std. Error & & & & Tolerance & VIF \\
\hline \multirow[t]{6}{*}{1} & (Constant) & -4.598 & 1.280 & & -3.592 & .000 & & \\
\hline & L (X5) & .632 & .048 & .597 & 13.129 & .000 & .646 & 1.549 \\
\hline & ATT (X1) & .464 & .054 & .369 & 8.660 & .000 & .736 & 1.359 \\
\hline & $\mathrm{SN}(\mathrm{X} 2)$ & .221 & .112 & .089 & 1.973 & .049 & .652 & 1.533 \\
\hline & PBC (X3) & -.447 & .083 & -.229 & -5.366 & .000 & .733 & 1.364 \\
\hline & $\mathrm{P}(\mathrm{X} 4)$ & .512 & .114 & .203 & 4.474 & .000 & .649 & 1.542 \\
\hline
\end{tabular}

a. Dependent Variable: IB (Y)

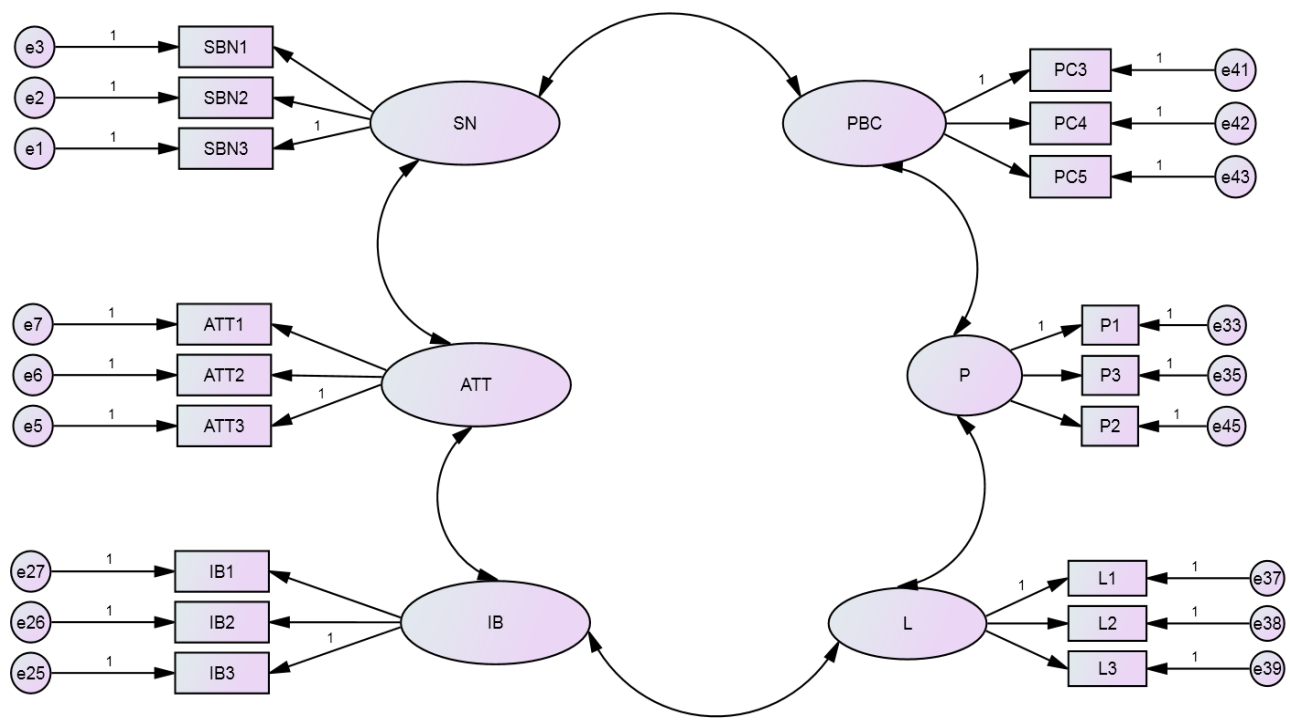

Figure 4. Measurement Model

Table 8.

Goodness of Fit results from the Measurement Model

\begin{tabular}{|c|c|c|c|c|}
\hline No & GOF Measures & Cut off Value & Default Model Value & Information \\
\hline \multicolumn{5}{|c|}{ Absolute fit Indices } \\
\hline 1 & GFI & Close to 1.00 & 0.737 & Fit \\
\hline 2 & AGFI & Close to 1.00 & 0.651 & Fit \\
\hline 3 & RMR & Close to 0.00 & 0.128 & Fit \\
\hline \multicolumn{5}{|c|}{ Incremental of Indices } \\
\hline 4 & NFI & Close to 1.00 & 0.734 & Fit \\
\hline 5 & CFI & Close to 1.00 & 0.754 & Fit \\
\hline 6 & IFI & Close to 1.00 & 0.755 & Fit \\
\hline 7 & RFI & Close to 1.00 & 0.684 & Fit \\
\hline 8 & TLI & Close to 1.00 & 0.708 & Fit \\
\hline \multicolumn{5}{|c|}{ Parsimony Fit Indices } \\
\hline 9 & PRATIO & Close to 1.00 & 0.843 & Fit \\
\hline 10 & PNFI & Close to 1.00 & 0.619 & Fit \\
\hline 11 & PCFI & Close to 1.00 & 0.636 & Fit \\
\hline
\end{tabular}


Table 9.

Output Regression Weight

\begin{tabular}{lrrrlr}
\hline & Estimate & S.E. & C.R. & P & Label \\
\hline SBN3 <--- SN & 1 & & & & \\
SBN2 <--- SN & 0.786 & 0.123 & 6.387 & $* * *$ & \\
SBN1 <--- SN & 0.606 & 0.116 & 5.245 & $* * *$ & \\
ATT3 <--- ATT & 1 & & & & \\
ATT2 <--- ATT & 0.996 & 0.04 & 24.992 & $* * *$ & \\
ATT1 <--- ATT & 0.969 & 0.04 & 24.187 & $* * *$ & \\
P1 <--- P & 1 & & & & \\
P3 <--- P & 1.143 & 0.227 & 5.028 & $* * *$ & \\
L1 <--- L & 1 & & & & \\
L2 <--- L & 1.066 & 0.041 & 25.909 & $* * *$ & \\
L3 <--- L & 0.765 & 0.063 & 12.196 & $* * *$ & \\
PC3 <--- PBC & 1 & & & & \\
PC4 <--- PBC & 3.514 & 0.78 & 4.503 & $* * *$ & \\
PC5 <--- PBC & 3.409 & 0.742 & 4.592 & $* * *$ & \\
P2 <--- P & 2.205 & 0.458 & 4.818 & $* * *$ & \\
IB3 <--- IB & 1 & & & & \\
IB2 <--- IB & 1.26 & 0.061 & 20.564 & $* * *$ & \\
IB1 <--- IB & 1.014 & 0.06 & 16.964 & $* * *$ & \\
\hline \hline
\end{tabular}

Table 10

Output Standardized Regression Weights

\begin{tabular}{lc}
\hline \hline & Estimate \\
\hline SBN3 <--- SN & 0.719 \\
SBN2 <--- SN & 0.512 \\
SBN1 <--- SN & 0.394 \\
ATT3 <-- ATT & 0.855 \\
ATT2 <--- ATT & 0.969 \\
ATT1 <--- ATT & 0.948 \\
P1 <--- P & 0.393 \\
P3 <--- P & 0.581 \\
L1 <-- L & 0.912 \\
L2 <--- L & 0.965 \\
L3 <--- L & 0.609 \\
PC3 <--- PBC & 0.26 \\
PC4 <--- PBC & 0.996 \\
PC5 <--- PBC & 0.871 \\
P2 <--- P & 0.766 \\
IB3 <--- IB & 0.796 \\
IB2 <--- IB & 1.003 \\
IB1 <--- IB & 0.826 \\
\hline \hline
\end{tabular}

Table 11.

CR \& AVE Calculation Results

\begin{tabular}{|c|c|c|c|c|c|c|}
\hline LATENT VARIABEL & INDIC. & LOADING FACTOR & LOADING FACTOR $^{2}$ & 1-LOADING FACTOR ${ }^{2}$ & $\mathbf{C R}$ & AVE \\
\hline \multirow{5}{*}{ IB } & IB1 & 0.826 & 0.682 & 0.318 & \multirow{5}{*}{0.91} & \multirow{5}{*}{0.774} \\
\hline & IB2 & 1.003 & 1.006 & -0.006 & & \\
\hline & IB3 & 0.796 & 0.634 & 0.366 & & \\
\hline & $\sum$ & 2.625 & 2.322 & 0.678 & & \\
\hline & $\Sigma^{2}$ & 6.8906 & & & & \\
\hline \multirow{5}{*}{ ATT } & ATT1 & 0.948 & 0.899 & 0.101 & \multirow{5}{*}{0.947} & \multirow{5}{*}{0.856} \\
\hline & ATT2 & 0.969 & 0.939 & 0.061 & & \\
\hline & ATT3 & 0.855 & 0.731 & 0.269 & & \\
\hline & $\Sigma$ & 2.772 & 2.569 & 0.431 & & \\
\hline & $\sum^{2}$ & 7.684 & & & & \\
\hline \multirow{5}{*}{ SN } & SN1 & 0.394 & 0.155 & 0.845 & \multirow{5}{*}{0.561} & \multirow{5}{*}{0.311} \\
\hline & $\mathrm{SN} 2$ & 0.512 & 0.262 & 0.738 & & \\
\hline & $\mathrm{SN} 3$ & 0.719 & 0.517 & 0.483 & & \\
\hline & $\Sigma$ & 1.625 & 0.934 & 2.066 & & \\
\hline & $\sum^{2}$ & 2.6406 & & & & \\
\hline \multirow{5}{*}{$\mathrm{PBC}$} & $\overline{\mathrm{PBC} 3}$ & 0.26 & 0.068 & 0.932 & \multirow{5}{*}{0.793} & \multirow{5}{*}{0.606} \\
\hline & PBC4 & 0.996 & 0.992 & 0.008 & & \\
\hline & PBC5 & 0.871 & 0.759 & 0.241 & & \\
\hline & $\Sigma$ & 2.127 & 1.818 & 1.182 & & \\
\hline & $\Sigma^{2}$ & 4.5241 & & & & \\
\hline \multirow{5}{*}{$\mathrm{P}$} & P1 & 0.393 & 0.154 & 0.846 & \multirow{5}{*}{0.612} & \multirow{5}{*}{0.36} \\
\hline & P2 & 0.766 & 0.587 & 0.413 & & \\
\hline & P3 & 0.581 & 0.338 & 0.662 & & \\
\hline & $\Sigma$ & 1.74 & 1.079 & 1.921 & & \\
\hline & $\Sigma^{2}$ & 3.0276 & & & & \\
\hline \multirow{5}{*}{$\mathrm{L}$} & L1 & 0.912 & 0.832 & 0.168 & \multirow{5}{*}{0.877} & \multirow{5}{*}{0.711} \\
\hline & L2 & 0.965 & 0.931 & 0.069 & & \\
\hline & L3 & 0.609 & 0.371 & 0.629 & & \\
\hline & $\Sigma$ & 2.486 & 2.134 & 0.866 & & \\
\hline & $\sum^{2}$ & 6.1802 & & & & \\
\hline
\end{tabular}

data that must meet normality assumptions so that the data can still be used for processed.

2) Linearity Test

From Figure 3 it can be seen that the results of scatterplot analysis show that the relationship between variables is linear for the relationship between the latent variables IB with ATT,
SN, PBC, P \& L variables. From Figure 3 it can be seen that the results of scatterplot analysis show that the relationship between variables is linear for the relationship between the latent variables IB with ATT, SN, PBC, P \& L variables.

From Table 6 above it is known that the results of the $F$ test / significance test (Sig.) $<0.05$ for the relationship between 
Table 12.

Output Regression Weight Covariance

\begin{tabular}{lccccc}
\hline \hline & Estimate & S.E. & C.R. & P & Label \\
\hline P <--> PBC & 0.003 & 0.003 & 0.942 & 0.346 & \\
P <--> L & 0.075 & 0.019 & 3.949 & $* * *$ & \\
SN <--> PBC & 0.042 & 0.011 & 3.767 & $* * *$ & \\
SN <--> ATT & 0.117 & 0.024 & 4.934 & $* * *$ & \\
ATT <--> IB & 0.234 & 0.041 & 5.661 & $* * *$ & \\
L <--> IB & 0.58 & 0.069 & 8.384 & $* * *$ & \\
\hline \hline
\end{tabular}

Table 13.

Output Estimate Standardized Regression Weight Covariance

\begin{tabular}{lc}
\hline \hline & Estimate \\
\hline P <--> PBC & 0.058 \\
P <--> L & 0.321 \\
SN <--> PBC & 0.563 \\
SN <--> ATT & 0.34 \\
ATT <--> IB & 0.28 \\
L <--> IB & 0.625 \\
\hline \hline
\end{tabular}

Table 14.

Results of Correlation Between Latent Variables

\begin{tabular}{ccc}
\hline \hline KORELASI (r) & \multicolumn{2}{c}{ KORELASI KUADRAT (r2) } \\
\hline 0.058 & 0.003364 & $0 \%$ \\
0.321 & 0.103041 & $10 \%$ \\
0.563 & 0.316969 & $32 \%$ \\
0.34 & 0.1156 & $12 \%$ \\
0.28 & 0.0784 & $8 \%$ \\
0.625 & 0.390625 & $39 \%$ \\
\hline
\end{tabular}

IB variables with ATT, SN, PBC, P \& L so that the regression model meets the linearity criteria.

From table 7 above it is known that the Tolerance value of each independent variable $>0.10$ and the VIF value of each independent variable $<10.00$ then it means that there is no multicollinearity in the regression model.

3) Analysis of Structural Equation Model (SEM)

a. Making of Measurement Model \& Validity Test

The measurement model and result of goodness of fit can be seen in Figure 4 and Table 8.

b. Analysis of Relationship Indicators \& Laten Variables

1. Probability of Indicators

From the results of the above output, it can be seen that the probability value $(\mathrm{p})$ is $* * *(\mathrm{p}<0.001)$ which means that $\mathrm{H} 0$ is rejected / all have a real relationship between the indicator and the latent variable.

From the results of the above output, it can be seen that the probability value $(\mathrm{p})$ is $* * *(\mathrm{p}<0.001)$ which means that $\mathrm{H} 0$ is rejected / all have a real relationship between the indicator and the latent variable.

\section{Loading Factors of Indicators}

Based on Table 10 above, the average loading factor value $>0.5$ is obtained, this shows the indicator has a strong relationship with the latent variable. On the other hand there are several indicators that have a relationship $<0.5$, namely SN1, P1 \& PBC3, which means that the indicator has a weak relationship to the latent variable.

\section{Reliability Test}

Based on table 11 it can be seen that the $\mathrm{CR}$ value $>0.70$ for latent variables IB, ATT, PBC, P \& L has a good consistency value unless the latent variable $\mathrm{SN}$ has a $\mathrm{CR}$
Table 15

Output Squared Multiple Correlations

\begin{tabular}{cc}
\hline & Estimate \\
\hline P2 & 0.587 \\
PC5 & 0.758 \\
PC4 & 0.992 \\
PC3 & 0.068 \\
L3 & 0.371 \\
L2 & 0.931 \\
L1 & 0.832 \\
P3 & 0.337 \\
P1 & 0.154 \\
IB1 & 0.682 \\
IB2 & 1.006 \\
IB3 & 0.633 \\
ATT1 & 0.898 \\
ATT2 & 0.938 \\
ATT3 & 0.732 \\
SBN1 & 0.155 \\
SBN2 & 0.262 \\
SBN3 & 0.516 \\
\hline \hline
\end{tabular}

value of $<0.70$ has a poor consistency value. As for the AVE value $>0.5$ for latent variables IB, ATT, PBC \& L \& smaller than the $\mathrm{CR}$ value it has an adequate convergence value except for one latent variable SN \& $\mathrm{P}$ has a value of AVE $<0.5$.

4. Probability Relationship Between Variables

Based on Table 12 above, it can be seen that the probability value (p) is $* * *$ or $<0.05$ which means that there is a real relationship between the latent variables P \& L, SN \& PBC, SN \& ATT, ATT \& IB and L \& IB on the other hand there is a significant relationship between the latent variable P \& PBC because it has a probability value $(p)>0.05$

5. Loading Factors Relationship Between Variables

Based on Table 13 above, the loading factor value $>0.5$ is obtained and it is positive for the relationship between the SN \& PBC latent variable and L \& IB, this shows that the latent variable has a strong relationship and has a direct relationship, for example, between L \& IB when the greater the level lifestyle, the greater the greater the desire to buy apartments from consumers (IB). In addition there are several latent variables that have a relationship $<0.5$ and are positive, namely P \& PBC, P \& L, SN \& ATT and ATT \& IB, which means that these latent variables have a weak relationship and have a direct relationship.

6. Discriminant Validity Test

Based on Table 14 above, the correlation squared results obtained are $0 \%, 10 \%, 32 \%, 12 \%$, and $39 \%$ where the value is smaller than the AVE value of $77 \%, 86 \%, 31 \%, 61 \%$ and $36 \%$, and $71 \%$ this shows that the relationship between latent variables is weak and shows that the six latent variables can indeed be distinguished from one another (discriminant). Thus the six latent variables have been declared to meet the discriminant test.

7. Variations of Indicators

Based on Table 15 above, it can be seen that the variation of IB2 manifest variable / indicator can be explained by the latent variable IB (Intention Behavior) up to $100.6 \%$ while the variation of PBC3 manifest / indicator variable can be 


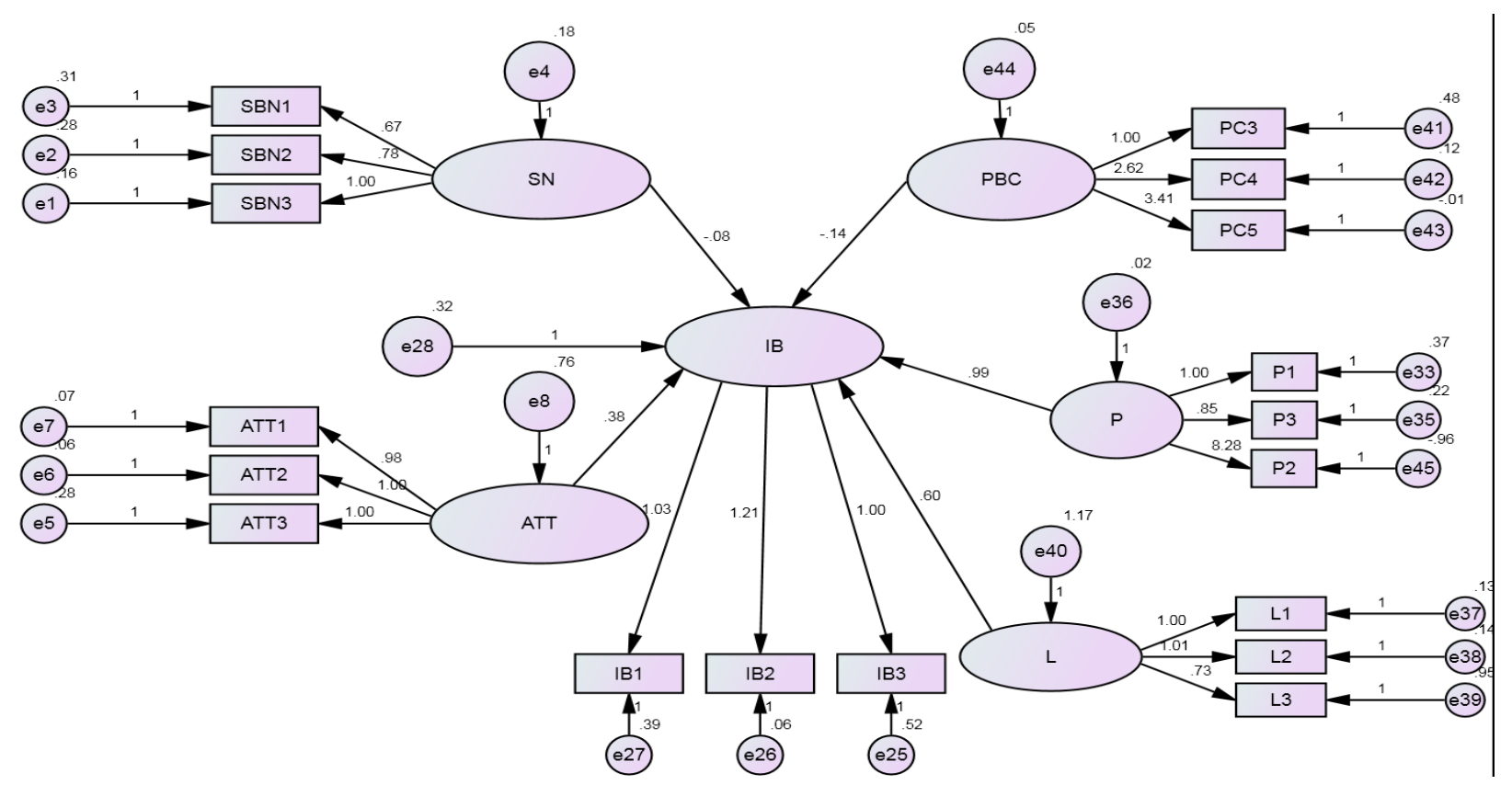

Figure 5. Structural Model Test Results

Table 16.

GoF Results from Structural Models

\begin{tabular}{|c|c|c|c|c|}
\hline No & GoF Measures & Cut off Value & Default Model Value & Information \\
\hline \multicolumn{5}{|c|}{ Absolute fit Indices } \\
\hline 1 & GFI & Close to 1.00 & 0.717 & Fit \\
\hline 2 & AGFI & Close to 1.00 & 0.628 & Fit \\
\hline 3 & RMR & Close to 0.00 & 0.545 & Fit \\
\hline \multicolumn{5}{|c|}{ Incremental of Indices } \\
\hline 4 & NFI & Close to 1.00 & 0.718 & Fit \\
\hline 5 & CFI & Close to 1.00 & 0.739 & Fit \\
\hline 6 & IFI & Close to 1.00 & 0.74 & Fit \\
\hline 7 & RFI & Close to 1.00 & 0.669 & Fit \\
\hline 8 & TLI & Close to 1.00 & 0.692 & Fit \\
\hline \multicolumn{5}{|c|}{ Parsimony Fit Indices } \\
\hline 9 & PRATIO & Close to 1.00 & 0.85 & Fit \\
\hline 10 & PNFI & Close to 1.00 & 0.61 & Fit \\
\hline 11 & PCFI & Close to 1.00 & 0.628 & Fit \\
\hline
\end{tabular}

explained by the latent variable PBC (Perceived Behavior Control) to $6.8 \%$. But overall, by squaring the correlation value (in the standardized regression weight) section, a high enough value will be obtained.

c. Making of Structural Model \& Validity Test

The measurement model and result of goodness of fit can be seen in Figure 5 and Table 16.

d. Analysis of Relationship between Variables with Bootstrap

1. Probability (p-value)

From Table 17, the probability values (p) obtained are as follows:va) $\mathrm{ATT} \& \mathrm{IB}=0,001$; b) P \& IB $=0,003$; c) $\mathrm{L} \&$ $\mathrm{IB}=0,001$; d) $\mathrm{SN} \& \mathrm{IB}=0,705$; e) $\mathrm{PBC} \& \mathrm{IB}=0,705$

Based on the results of the analysis above the hub. between significant latent variables \& models according to the hypothesis

2. Estimated Value of the Parameter Coefficient

Based on Table 18, it can be seen that the parameter coefficient values are as follows: a) ATT \& IB =0,378 (H1); b) P \& IB $=0,992(\mathrm{H} 2)$; c) $\mathrm{L} \& \mathrm{IB}=0,605(\mathrm{H} 3)$; d) $\mathrm{SN} \quad \&$ $\mathrm{IB}=-0,083(\mathrm{H} 4)$; e)PBC \& IB $=-0,137$ (H5).

3. Reliability Test

Based on Table 19, it can be seen that the $\mathrm{CR}$ value $>0.70$ for latent variables IB, ATT, PBC, P \& L has a good consistency value unless the latent variable $\mathrm{SN}$ has a $\mathrm{CR}$ value of 0.70 has a poor consistency value. As for the AVE value $>0.5$ for latent variables IB, ATT, PBC, P \& L \& smaller than the $\mathrm{CR}$ value it has an adequate convergence value except for one latent variable $\mathrm{SN}$ has a value of $\mathrm{AVE}<$ 0.5 .

e. Hypothesis Test

This hypothesis test is conducted to determine whether there is an influence of exogenous variables on endogenous variables, used by comparing the probability ( $p$ ) from table 17 above and the CR values from table 18 summarized in Table 20.

From Table 20, the C.R value is calculated in the Regression Weight table with a positive value for the 
Table 17.

Output Bias-Corrected Percentile Method

\begin{tabular}{lrrrr}
\hline \hline Parameter & Estimate & Lower & Upper & P \\
\hline IB <--- ATT & 0.378 & 0.247 & 0.509 & 0.001 \\
IB <--- P & 0.992 & 0.65 & 1.512 & 0.003 \\
IB <--- L & 0.605 & 0.495 & 0.741 & 0.001 \\
IB <--- SN & -0.083 & -0.403 & 0.565 & 0.705 \\
IB <--- PBC & -0.137 & -0.946 & 0.848 & 0.705 \\
SBN3<--- SN & 1 & 1 & 1 & $\ldots$ \\
SBN2<--- SN & 0.785 & 0.302 & 1.877 & 0.001 \\
SBN1 <--- SN & 0.669 & 0.208 & 1.136 & 0.002 \\
ATT3<--- ATT & 1 & 1 & 1 & $\ldots$ \\
ATT2<-- ATT & 0.997 & 0.935 & 1.063 & 0.001 \\
ATT1<--- ATT & 0.98 & 0.91 & 1.06 & 0.001 \\
P1 <--- P & 1 & 1 & 1 & $\ldots$ \\
P3 <--- P & 0.853 & 0.588 & 1.207 & 0.005 \\
L1 <--- L & 1 & 1 & 1 & $\ldots$ \\
L2 <--- L & 1.015 & 0.936 & 1.111 & 0.005 \\
L3 <--- L & 0.725 & 0.556 & 0.861 & 0.005 \\
PC3 <--- PBC & 1 & 1 & 1 & $\ldots$ \\
PC4 <--- PBC & 2.622 & 1.83 & 5.449 & 0.001 \\
PC5 <--- PBC & 3.408 & 2.353 & 9.13 & 0.001 \\
P2 <--- P & 8.285 & 4.54 & 18.611 & 0 \\
IB3 <--- IB & 1 & 1 & 1 & $\ldots$ \\
IB2 <--- IB & 1.214 & 1.12 & 1.329 & 0.004 \\
IB1 <--- IB & 1.031 & 0.908 & 1.174 & 0.002 \\
\hline
\end{tabular}

Table 18.

Output Regression Weight

\begin{tabular}{lccccc}
\hline & Estimate & S.E. & C.R. & P & Label \\
\hline IB <--- ATT & 0.378 & 0.056 & 6.797 & $* * *$ & par_5 \\
IB <--- P & 0.992 & 0.208 & 4.758 & $* * *$ & par_7 \\
IB <--- L & 0.605 & 0.05 & 12.079 & $* * *$ & par_10 \\
IB <--- SN & -0.083 & 0.146 & -0.565 & 0.572 & par_14 \\
IB <--- PBC & -0.137 & 0.229 & -0.597 & 0.55 & par_15 \\
SBN3 <--- SN & 1 & & & & \\
SBN2 <--- SN & 0.785 & 0.211 & 3.729 & $* * *$ & par_1 \\
SBN1 <--- SN & 0.669 & 0.176 & 3.803 & $* * *$ & par_2 \\
ATT3 <--- ATT & 1 & & & & \\
ATT2 <--- ATT & 0.997 & 0.04 & 25.047 & $* * *$ & par_3 \\
ATT1 <--- ATT & 0.98 & 0.041 & 23.991 & $* * *$ & par_4 \\
P1 <--- P & 1 & & & & \\
P3 <--- P & 0.853 & 0.157 & 5.427 & $* * *$ & par_6 \\
L1 <--- L & 1 & & & & \\
L2 <--- L & 1.015 & 0.037 & 27.132 & $* * *$ & par_8 \\
L3 <--- L & 0.725 & 0.06 & 12.066 & $* * *$ & par_9 \\
PC3 <--- PBC & 1 & & & & \\
PC4 <--- PBC & 2.622 & 0.481 & 5.449 & $* * *$ & par_11 \\
PC5 <--- PBC & 3.408 & 0.717 & 4.756 & $* * *$ & par_12 \\
P2 <--- P & 8.285 & 5.245 & 1.58 & 0.114 & par_13 \\
IB3 <--- IB & 1 & & & & \\
IB2 <--- IB & 1.214 & 0.057 & 21.476 & $* * *$ & par_16 \\
IB1 <--- IB & 1.031 & 0.058 & 17.663 & $* * *$ & par_17 \\
\hline \hline
\end{tabular}

Table 19.

CR \& AVE Calculation Results

\begin{tabular}{|c|c|c|c|c|c|c|}
\hline VARIABEL LATEN & INDIC. & LOADING FACTOR & LOADING FACTOR $^{2}$ & 1-LOADING FACTOR ${ }^{2}$ & CR & AVE \\
\hline \multirow{5}{*}{ IB } & IB1 & 0.84 & 0.706 & 0.294 & \multirow{5}{*}{0.905} & \multirow{5}{*}{0.763} \\
\hline & IB2 & 0.976 & 0.953 & 0.047 & & \\
\hline & IB3 & 0.794 & 0.63 & 0.37 & & \\
\hline & $\Sigma$ & 2.61 & 2.289 & 0.711 & & \\
\hline & $\Sigma^{2}$ & 6.8121 & & & & \\
\hline \multirow{5}{*}{ ATT } & ATT1 & 0.955 & 0.912 & 0.088 & \multirow{5}{*}{0.947} & \multirow{5}{*}{0.858} \\
\hline & ATT2 & 0.965 & 0.931 & 0.069 & & \\
\hline & ATT3 & 0.854 & 0.729 & 0.271 & & \\
\hline & $\sum$ & 2.774 & 2.573 & 0.427 & & \\
\hline & $\sum^{2}$ & 7.6951 & & & & \\
\hline \multirow{5}{*}{$\mathrm{SN}$} & SN1 & 0.458 & 0.21 & 0.79 & \multirow{5}{*}{0.602} & \multirow{5}{*}{0.344} \\
\hline & SN2 & 0.534 & 0.285 & 0.715 & & \\
\hline & $\mathrm{SN} 3$ & 0.733 & 0.537 & 0.463 & & \\
\hline & $\sum$ & 1.725 & 1.032 & 1.968 & & \\
\hline & $\sum^{2}$ & 2.9756 & & & & \\
\hline \multirow{5}{*}{$\mathrm{PBC}$} & PBC3 & 0.303 & 0.092 & 0.908 & \multirow{5}{*}{0.804} & \multirow{5}{*}{0.616} \\
\hline & $\mathrm{PBC} 4$ & 0.86 & 0.74 & 0.26 & & \\
\hline & PBC5 & 1.009 & 1.018 & -0.018 & & \\
\hline & $\Sigma$ & 2.172 & 1.849 & 1.151 & & \\
\hline & $\sum^{2}$ & 4.7176 & & & & \\
\hline \multirow{5}{*}{$\mathrm{P}$} & P1 & 0.234 & 0.055 & 0.945 & \multirow{5}{*}{1.01} & \multirow{5}{*}{1.016} \\
\hline & P2 & 1.711 & 2.928 & -1.928 & & \\
\hline & P3 & 0.258 & 0.067 & 0.933 & & \\
\hline & $\Sigma$ & 2.203 & 3.049 & -0.049 & & \\
\hline & $\sum^{2}$ & 4.8532 & & & & \\
\hline \multirow{5}{*}{$\mathrm{L}$} & L1 & 0.95 & 0.903 & 0.098 & \multirow{5}{*}{0.888} & \multirow{5}{*}{0.731} \\
\hline & L2 & 0.947 & 0.897 & 0.103 & & \\
\hline & L3 & 0.628 & 0.394 & 0.606 & & \\
\hline & $\Sigma$ & 2.525 & 2.194 & 0.806 & & \\
\hline & $\sum^{2}$ & 6.3756 & & & & \\
\hline
\end{tabular}

relationship between exogenous variables ATT, P \& L for IB endogenous variables while C.R values are calculated with a negative value for the relationship between $\mathrm{SN} \& \mathrm{PBC}$ exogenous variables for IB endogenous variables. In addition, p-value $<0.05$ was obtained for the relationship between exogenous variables ATT, P \& L for endogenous variables
IB meaning that $\mathrm{H} 0$ was accepted or significant, while $\mathrm{p}$ value $>0.05$ for the relationship between exogenous variables $\mathrm{SN} \& \mathrm{PBC}$ for endogenous variables IB means H0 is rejected or insignificant. More details will be explained in the next section. From Table 21, it can be concluded that in this study there were 3 accepted hypotheses and 2 hypotheses were 
The $1^{\text {st }}$ International Conference on Business and Engineering Management (IConBEM)

February $1^{\text {st }} 2020$, Institut Teknologi Sepuluh Nopember, Surabaya, Indonesia

Table 20.

Hypothesis Test Results

\begin{tabular}{cccc}
\hline Relationship Between Variabel & C.R & Probability (P) & Information \\
\hline IB <--- ATT & 6.797 & 0.001 & Significant \\
IB <--- P & 4.758 & 0.003 & Significant \\
IB <--- L & 12.079 & 0.001 & Significant \\
IB <--- SN & -0.565 & 0.705 & Not significant \\
IB <--- PBC & -0.597 & 0.705 & Not significant \\
\hline \hline
\end{tabular}

Table 21.

Hypothesis Test Analysis Results

\begin{tabular}{llc}
\hline \hline & \multicolumn{1}{c}{ Hypothesis } & Analysis Results \\
\hline H1 & Attitude (ATT) significant effect on Intention Behavior (IB) & Accepted \\
H2 & Perception (P) significant effect on Intention Behavior (IB) & Accepted \\
H3 & Lifestyle (L) significant effect on Intention Behavior (IB) & Accepted \\
H4 & Subjective Norms (SN) significant effect on Intention Behavior (IB) & Rejected \\
H5 & Perceived Behavior Control (PBC) significant effect on Intention Behavior (IB) & Rejected \\
\hline \hline
\end{tabular}

rejected in which 3 factors that influence consumer behavior intentions when buying an apartment are Attitude (ATT), Perception (P) and Lifestyle (L) while 2 factors which do not influence the intention to behave when making apartment purchases are Subjective Norms (SN) and Perceived Behavior Control (PBC).

\section{CONCLUSION}

The conclusions from the results of the analysis and discussion of this study are the factors that influence consumer behavior intentions when making apartment purchases in terms of the Extended Theory of Planned Behavior, among others, as follows:

1. From several factors viewed from the Extended Theory of Planned Behavior, among others: Lifestyle (L), Perception (P), Perceived Behavior Control (PBC), Subjective Norms (SN) and Attitude (ATT) which are proven to positively influence consumer behavioral intentions when performing apartment purchases are the following 3 factors, among others: Attitude (ATT), Perception (P) and Lifestyle (L) while two other factors Subjective Norms (SN) and Perceived Behavior Control
(PBC) are proven not to affect consumer behavior intentions when making apartment purchases.

2. Among the three factors that influence the consumer's intention to behave when purchasing an apartment sorted according to the coefficient value and the highest level of significance to the lowest are as follows: (1) Lifestyle (L) with a $C R$ value $=12,079$ with a probability $(p)=0.001$, (2) Attitude (ATT) with CR $=6,797$ with probability (p) $=0,001$, (3) Perception (P) with $\mathrm{CR}=4,758$ with probability $(\mathrm{p})=0,003$.

\section{REFERENCES}

[1] Colliers International, "Surabaya Property Market Report," Res. Forecast Rep., 2017.

[2] T. S. Al-Nahdi, S. A. Habib, and A. A. Albdour, "Factors influencing the intention to purchase real estate in Saudi Arabia: moderating effect of demographic citizenship," Int. J. Bus. Manag., vol. 10, no. 4, pp. 35-48, 2015, doi: 10.5539/ijbm.v10n4p35.

[3] K. M. Gibler and S. L. Nelson, "Consumer behavior applications to real estate education," J. Real Estate Pract. Educ., vol. 6, no. 1, pp. 63-83, 2003

[4] T. S. AL-Nahdi, E. Nyakwende, A. M. Banamah, and A. A. Jappie, "Factors affecting purchasing behavior in real estate in saudi arabia,” Int. J. Bus. Soc. Sci., vol. 6, no. 2, pp. 113-125, 2015. 